\title{
The Dynamics of the Islamic Publishers in Indonesia: a Case Study of the Publisher Gema Insani Press Jakarta (1986-2011)
}

\author{
Abd. Chair \\ Islamic History and Culture Department \\ Syarif Hidayatullah State Islamic University Jakarta, Indonesia \\ abd.chair@uinjkt.ac.id
}

\begin{abstract}
Gema Insani Press (GIP) is one of the Islamic publishers that have emerged in Indonesia since 1980s. GIP has been publishing many Islamic books in Indonesian. GIP also published the books translated from Arabic into Indonesian authored by prominent Muslim intellectuals of the Middle East, such as Sayyid Qutb, Muhammad Qutb, Muhammad al-Ghazali, and Muslim Brothers (al-Ikhwan al-Muslimin). This paper aims to study whether or not GIP purely positions itself as an ordinary Islamic publisher for the shake of the economic benefit or as a publisher that disseminates a particular ideology. To answer this question, I collect the official documents of GIP and in-depth interviews with the key staff of GIP to understand their views on social, political and religious issues in Indonesia. I strengthen this approach by employing content analysis to the published books by GIP. I argue that GIP has positioned itself as a party supporting literal and puritan Islamic teachings; thereby rejecting the liberal forms of Islamic thoughts and practices. GIP has turned to be a basis for puritan Muslims to perpetuate antiliberal Islam ideology. Therefore, this type of puritan Islamic books is sold out in Indonesia.
\end{abstract}

Keywords- The Islamic Publishers; Gema Insani Press; Islamism

\section{INTRODUCTION}

In the last few decades, the world of Indonesian publishing has been enlivened by the emergence of various Islamic publishers who were engaged in producing Islamic books. During the period 1981-1989, IKAPI (Indonesian Publisher Association) noted that the number of Islamic publishers is only 6 publishers[1, p. 275], then in 2011, out of 1009 publishers registered in IKAPI, almost half of them specialize in publishing Islamic books[2].

At the same time, supported by a large number of Islamic publishers, since 2001, the Islamic Book Fair (IBF) - a national exhibition organized exclusively for Islamic booksis held in Jakarta every year. The event was also attended by other areas besides Jakarta in recent years. This development, at least, indicates that Islamic books have become an important category in Indonesian publishing.

Islamic publishers began popping up the publishing in Indonesia in the $80 \mathrm{~s}$. This occurred along with the economic progress of the late 1970s and throughout the 1980s. On the other hand, the influence of Iran's Islamic Revolution was, in

fact, also influential in the process of development of Islamic publishers. The Iranian revolutionary fever in its development has also influenced the Indonesian government to further simplify all Muslim expressions and opinions.

The first development of this situation was the translation of literary Muslim writers' works that pursued puritanical Islam, such as Maulana Al-Maududi from Pakistan. The other development of this situation was the emergence of Islamic publishers that aimed to participate in disseminating Islamic teachings more widely. It was Mizan in Bandung who finally started the agenda of dissemination of Islamic teachings. In 1983, Mizan was present as an Islamic publisher to provide a balanced idealized Islamic picture. For that purpose, Mizan seeks to publish works of contemporary Islamic thought, both written by Indonesian and foreign intellectuals.

After the emergence of Mizan, it appeared next publisher Gema Insani Press (GIP) in 1986. Founded in Jakarta by Umar Basyarahil, GIP appeared with its first translation work of the Afghan War. This book in its history was quite successful. The success prompted the GIP to publish books of other translations from Middle Eastern writers such as Sayyid Qutb, Muhammad Qutb and Muhammad al-Ghazali and works of other al-Ikhwan al Muslimun writers.

\section{METHOD}

The method used in this research was formulated in accordance with the needs of data types to be explored. Data on the attitude and views of GIP officials were done through in-depth interviews with a number of key GIP figures. The same method was also used in the context of tracking their perceptions as well as their views on social, political and religious issues in Indonesia. Whereas, the data concerning institutional institutions GIP excavated, either through document studies (bibliographic) or in-depth interviews with a number of GIP publishers.

To see the tendency of published books, it used content analysis. This step was used to analyze matters relating to the 
contents of Islamic books from GIP publishers, including seeing various titles, authors, field studies and discussion categories. The existing works were then identified, inventoried and analyzed, for further known patterns, characteristics, trends, and discourse directions that the GIP publisher was trying to develop.

\section{RESULT AND DISCUSSION}

As an Islamic publisher that has emerged for more than three decades, GIP has been recognized as one of the great Islamic publishers after Mizan[2, p. 186]. In the early years of its existence GIP publishes many books which then became much of a reference and favored by general Islamic students. GIP books are often used as reference material for the activities of tarbiyah, or Islamic student study club in many public colleges[2, p. 194]. These Groups in its development allegedly support the establishment of the Prosperous Justice Party (Partai Keadilan Sejahtera/ PKS)[4].

GIP is often linked with the development of Islamic $d a^{\prime}$ wah movement which in fact is very lively lately. GIP seems to actively publish the works of al-Ikhwan alMuslimun (Muslim Brotherhood) and their sympathizers, who are opposed to liberal Islam, progressive or Islamic style that upholds freedom of thought and always struggles for contemporary Islamic issues such as pluralism, secularization and other issues. In that position, the GIP often provides more literal and puritan Islamic teachings.

Here it appears that GIP, as well as other Islamic publishers, ultimately plays a major role in spreading Islamic values in Indonesia. Even further, through Islamic publishers, the spread of Islamic ideology strengthened and consequently helped determine the direction of Islamic development in general. Thus, the later discourse of Islam that colored religious life in Indonesia, also gained momentum strengthening along with the strengthening position of Islamic publishers in Indonesia.

The problem is, when Islamic publishers are present with a proprietary ideological mission that tends to be exclusive, it is hard to deny that this in turn will have an unhealthy impact on the development of Islam in Indonesia in general. When Islamic publishers have been from the beginning of positioning themselves as dissidents of certain ideologies, it is only natural that published works also arise with an ideological load. The study of publishing relations with dissemination of Islamic teachings has been done by several Islamic researchers both inside and outside Indonesia. Some of them, Howard M. Federspiel (1984), R.William Liddle (1996), Robet W. Hefner (1997), Dale F. Eickelman and Jon W.Anderson (1999), Azyumardi Azra (2001), Halid and Zubair (2003), CW. Watson (2005), Akh. Muzakki (2007). In general they set out from a similar perspective that media publishing such as books, newspapers, magazines, newsletters, pamphlets, or posters, especially those labeled Islam, have a strategic role for the intellectual transformation process of society in general. Therefore, the book will be a mediator in the effort to build the transformation of Islamic intellectualism in a society that is in some way very effective in influencing the mindset, attitude and behavior of its readers[5].

The Gema Insani Press (GIP) Publisher, founded in 1986 by Umar Basyarahil, clearly carries a certain ideology and has a mission to disseminate it through the published works. This is evident from his tendency to publish translations of books from the Middle East on various themes: tafsir, hadith, prophet history, creed, shari'a and worship, household and family, Islamic politics, and so on. Until now, GIP has successfully published various Islamic books both for the general public, teenagers, children, and to women's groups.

The first book published by GIP is Perang Afghanistan (the Afghan War). This book is very good in terms of sales. This achievement was in turn followed by the translation of other books from Middle Eastern writers, such as Sayyid Qutb, Muhammad Qutb, and Muhammad Al-Ghazali. However, its publications which focused on family and women's issues gave him a reputation as a publisher concentrating on domestic and personal issues.

Based on the Book Catalog of Gema Insani Press in 2011, until 2011 at least GIP has successfully published about 1464 titles of books covering the study of aqidah, Shariah, Syakhsiyah (Personality), Mar'ah (feminist), Islamic Politics, Da'wah, until of course review of harakah (Movement)[6].

Gema Insani Press Publisher (GIP) is trying to publish religious books with the trend of movement (harakah) or Islamic da'wah activities. As a publisher of Islam that has emerged for more than three decades, GIP is also widely known as one of the publishers of Islam that produces many books that become a reference material for tarbiyah activities or ta'lim (Islamic student study club) in many public colleges[3, p. 194].

Consequently, GIP is often associated with the development of Islamic propagation movement that in fact is very lively lately. In fact, the GIP appears to be actively publishing works of Muslim Brotherhood figures and their sympathizers, who are opposed to a liberal Islam, progressive or Islamic style that upholds freedom of thought and always strives for contemporary Islamic issues such as pluralism, secularization and various other issues.

This tendency seems reasonable given that the owner, Umar Basyarahil, was the son of an ustadz Al-Irsyad, an Arab-based non-sayyid (masyaikh) — was founded by Shaykh Ahmad As Surkati in 1914 in Jakarta-allegedly actively involved in the Wahabi movement / Salafi in Indonesia. Therefore, it is not surprising that the books are not far from Al-Irshad preaching. Therefore, it is not surprising that GIP more often provides a defense against the more literal and puritan Islamic teachings that tend to contradict liberal principles. And this can be seen at least from the diverse books he has published.

GIP is known as a publisher who prefers to translate works from the Middle East, especially al-Ikhwan al-Muslimun (Muslim Brotherhood) such as Hasan Al Banna, Sayyid Qutb, and Yusuf Qardhawi. Until 2003, it was noted that the GIP has translated about 25 titles of books by Yusuf Qardhawi. Overall, until 2003, GIP has successfully published 339 titles 
of translation work[5, p. 50-51]. Of the works are mostly themed harakah (movement). As it is known, from the beginning of the Middle East translation book in Indonesia, the theme of harakah has played a considerable role in the growth of Indonesian book.

Some of the translations published by this publisher are: Tujuan dan Sasaran Jihad (the Goals and Targets of Jihad) by Ali Bin Nafayyi 'al-Alyani (1992), Ujian, Cobaan, Fitnah dalam Dakwah (Trials and Defamation in Da'wah) by Dr. M. Abd. Qadir Abu Faris (1992), Tarbiyah Rasulullah (the Prophet Teachings) by Najib Khalid Al-Ami (1994), Dakwah Islam Dakwah Bijak (Islamic Wise Dakwah) by Said bin Ali al-Qahthani (1995), Ikhwanul Muslimin: Konsep Gerakan Terpadu (Ikhwanul Muslimin: The Concept of Integrated Movement) by Dr. Ali Abdul Halim Mahmud (1997), Panduan Jihad: Untuk Aktifis Gerakan Islam (Jihad Guide: For Islamic Movement Activists) by Dr. Hilmy Bakar Almascaty, M.A (2001), Pergerakan Muslimah Menyongsong Era Baru (The Movement of Muslimah Towards a New Era) by Amatullah Shafiyyah and Astriana (2002), Jundullah: Mengenal Intelektulitas dan Akhlak Tentara Allah (the Army of God: Knowing Intelligence and Moral Acts of the Army of God) by Said Hawwa (2002), Prinsip-prinsip Pendidikan Rasulullah Saw (Principles of Prophet's Education) by Prof. Dr. Alawi al Maliki (2002), Kebangkitan Islam di Andalusia (Islamic Awakening in Andalusia) by Ahmad Mahmud Himayah, 2004, Tarbiyah Jaadah by Muhammad ad-Duaisy (1998)[6].

In the context of the process of translating the works of Middle Eastern authors, the GIP uses a network of Indonesian students in the Middle East to undertake the process of translation. As spoken by Sahar L. Hasan, a former GIP Director, GIP always uses the services of students undertaking studies in the Middle East region to produce translation works. In addition to Indonesian students in the Middle East, GIP also uses the services of Islamic leaders who in fact have experience and adequate knowledge about the Middle East[7].

In the process of translating the works of the Middle East so far GIP relies on the translation agenda on $\mathrm{H}$. Salim Basyarahil. Some of the books he has translated include the History of the Gospel and the church (Tarikh al-Injil wa alKanisah) by Ahmad Idris (1991), Islamic Organization Facing the Christianization (Organisasi Islam Menghadapi Kristenisasi) of Khālid Na'īm (1991), the Largest Miracles of Isra 'Mi'raj (Isra' Mi'raj Mu'jizat Terbesar) by Muhammad Mutawallī Sha'rāwī (1992), Should Living with the Riba? (Haruskah Hidup dengan Riba?) of Yūsuf Qaraḍāwī (1991), War and Peace in the Reign of Prophet Muhammad (Perang dan Damai di Masa Pemerintahan Rasulullah) of Abdul Aziz Ghanim (1992), The Entertainment of the Believers (Hiburan Orang Mukmin) by Shafwak Sa'dallah Al Mukhtar (1992), Islam Speaks on Children (Islam Berbicara Soal Anak) by Karīmān Hamzah (1992), the God's Will (Qadha and Qadar) by Muḥammad Mutawallī Sha'rāwī (1988), The Opinion of Western Scholars and Philosophers on Islam (Pendapat Cendekiawan dan Filosof Barat tentang Islam) by Zakaria Hasyim Zakaria (1990), the Struggle of Muslim Female
Brotherhood (Perjuangan Wanita Ikhwanul Muslimin) by Zainab al Ghazali (1990), and Muhammad at the Eye of Western Scholar (Muhammad di Mata Cendekiawan Barat) by Asy Shaikh Khalil Yasien.

Because of the large number of published works by the writers of al-Ikhwan al- Muslimun (Muslim Brotherhood) and his supporters, the GIP positions actually itself as hostile to liberal forms of Islamic practice and thought, and further supports the more literal and puritan version of Islamic teachings.

By publishing the translated works of al-Ikhwan alMuslimin (Muslim Brotherhood) writers, the GIP raises an ideology of its own, Islamism. This ideology is broadly defined as an ideology that places Islam not only as a basis for religious belief but also as a basis of political doctrine. This is why; al-Qardhawi's translation books and Hasan al-Banna is always the prima donna of this publisher.

However, despite the ideology, the nature of the GIP publishing industry cannot be separated from the book publishing industry that seeks to supply the market demand of its readers. Not only are the books tailored to the needs of the middle class, with modern and painted formats, but the choice of themes and book content is increasingly widespread and expansive, not only on issues of harakah, but also on such topics as life families, teenagers, women's positions in Indonesian society, including even themes around business success tips. In fact, this pattern managed to deliver some books published GIP so sold in the market.

Thus, the GIP initially only published books that they considered as appropriate or under the spirit of da'wah alIrsyad-ideology that in fact is still strongly guarded by most administrators - currently, GIP seeks to adjust market tastes and as a result publish books requested by the general readers, especially Muslims. However, it is obviously a business strategy that GIP plays to adapt to market trends, since in truth, GIPs still routinely publish books that are in line with their mission and ideology, and will not get out of the GIP ideology rail that has been proclaimed from the beginning of this publisher was founded.

Therefore, the spirit of dakwah, or more firmly the character of the ideology of GIP Islamic publishers, eventually became a phenomenon that must be recognized and accepted in explaining the world of contemporary Islamic publishing. Moreover, as broad as any of the themes of Islamic publishers, when publishing books about Islam, they will obviously stick to a particular ideology or understanding of Islam he embraces.

\section{CONCLUSION}

Having summarized that Gema Insani Press (GIP) is a publisher that carries the ideology of Islamism, the ideology that puts Islam as the basis of religious belief and the basis of political doctrine. Therefore, this publisher has been translated many works of al-Ikhwan al-Muslimun writers that contain issues of harakah (movement). This ideology supports a more literal and puritan version of Islamic teaching that oppose to liberal Islamic practices and thought. Thus, this publisher is 
carrying the mission of disseminating that ideology.

\section{REFERENCES}

[1] Rizal Sukma, Clara Juwono, dan ed., Gerakan dan Pemikiran Islam Indonesia Kontemporer. Jakarta: CSIS, 2007.

[2] "http://www.ikapi.org/." [Daring]. Tersedia pada: http://www.ikapi.org/.

[3] Watson, C.W., "Islamic Books and Their Publishers: Notes on the Contemporary Indonesian Scene," J. Islam. Stud., vol. 16, no. 2, 2005.

[4] Damanik, Said Ali, Fenomena Partai Keadilan, Transformasi 20 Tahun Gerakan Tarbiyah di Indonesia. Bandung: Teraju, 2002.

[5] Halid dan Zubair, Peranan Penerbit dalam Transformasi Intelektualisme Islam: Survey terhadap Beberapa Penerbit Buku-buku Islam di Daerah Khusus Ibukota Jakarta. Jakarta: Lembaga Penelitian UIN Syarif Hidayatullah Jakarta, 2003.

[6] "http: www.gemainsani.co.id." [Daring]. Tersedia pada: http: www.gemainsani.co.id

[7] "interview," 16-Agu-2011. 